\title{
Twin reversed arterial perfusion (TRAP) sequence: an acardiac fetus
}

\section{Cátia Filipa Martins, ${ }^{1}$ Ana Vanessa Santos, ${ }^{2}$ Mariana Miranda ${ }^{2}$ Carla Granja ${ }^{1}$}

${ }^{1}$ Department of GynecologyObstetrics, Centro Hospitalar do Algarve, Portimão, Portugal ${ }^{2}$ Hospital Fernando Fonseca, Amadora, Portugal

\section{Correspondence to} Dr Cátia Filipa Martins, paixaocatia@gmail.com

Accepted 23 October 2014
CrossMark

To cite: Martins CF, Santos AV, Miranda M, et al. BMJ Case Rep Published online: [please include Day Month Year] doi:10.1136/ bcr-2014-207688

\section{DESCRIPTION}

A 32-year-old primigravida referred at 22 weeks with contractions. Ultrasound examination showed a $20 \mathrm{~mm}$ cervix and a monochorionic diamniotic pregnancy with one structurally normal fetus with hydramnios and a second twin anencephalic and acardiac (figure 1 and video 1). The patient was admitted with the diagnosis of twin reversed arterial perfusion (TRAP) and submitted to amnioreduction. A normal $46 \mathrm{XX}$ cariotype was obtained.

Owing to worsening of hydramnios and after counselling, the patient was sent to Hospital Clinic in Barcelona where a successful cord occlusion and laser ablation of the vascular anastomoses was performed at 25 weeks. Two weeks later, she was readmitted with premature rupture of membranes and delivered by C-section at 28 weeks due to severe oligohydramnios. A normal live fetus weighing $1005 \mathrm{~g}$ (figure 2) and a $135 \mathrm{~g}$ acardiac acephalus twin were born (figure 3). The autopsy

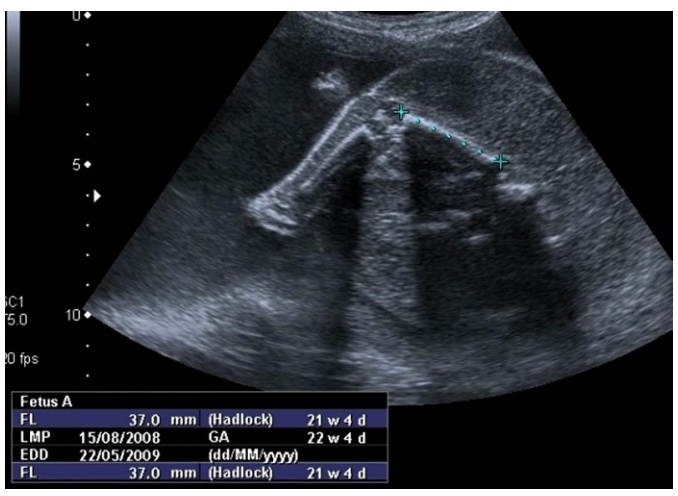

Figure 1 Acardiac fetus diagnosed during ultrasound examination.

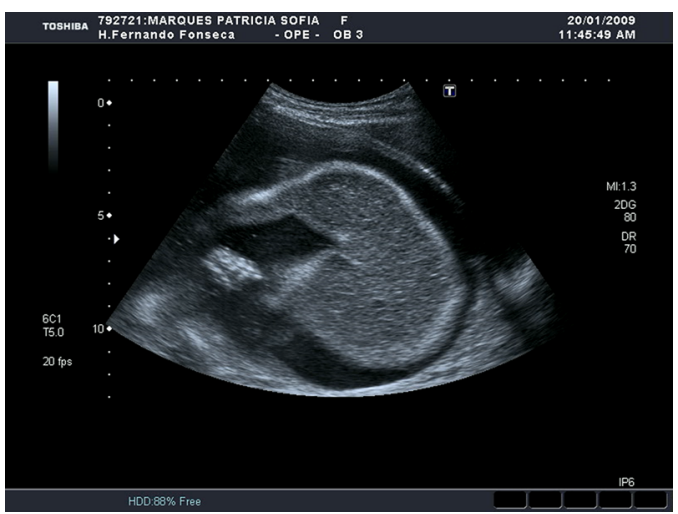

Video 1 Acardiac fetus diagnosed during ultrasound exam.

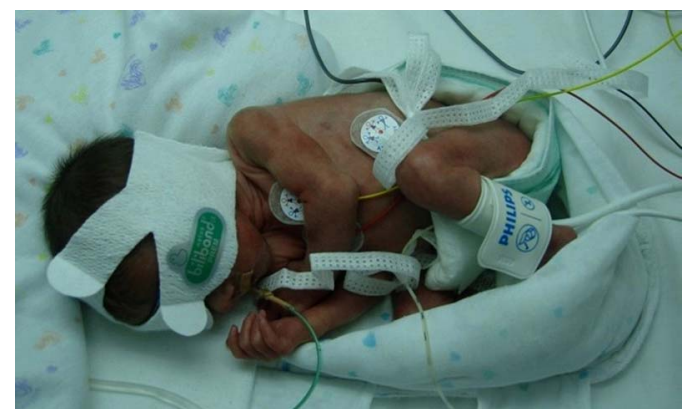

Figure 2 Normal female fetus in intensive care unit.

confirmed an acardiac twin with no fetal thoracic organs and absent head, a rudimentary bowel and deformed lower extremities (figures 4 and 5). The survival twin remained in the neonatal care unit due to prematurity-related complications and was discharged at 53 days of life.

TRAP is a unique complication of monochorionic twin pregnancy, in which a twin with an absent heart ('acardiac twin') is perfused by its co-twin ('pump twin') via placental arterial anastomoses. ${ }^{1}$

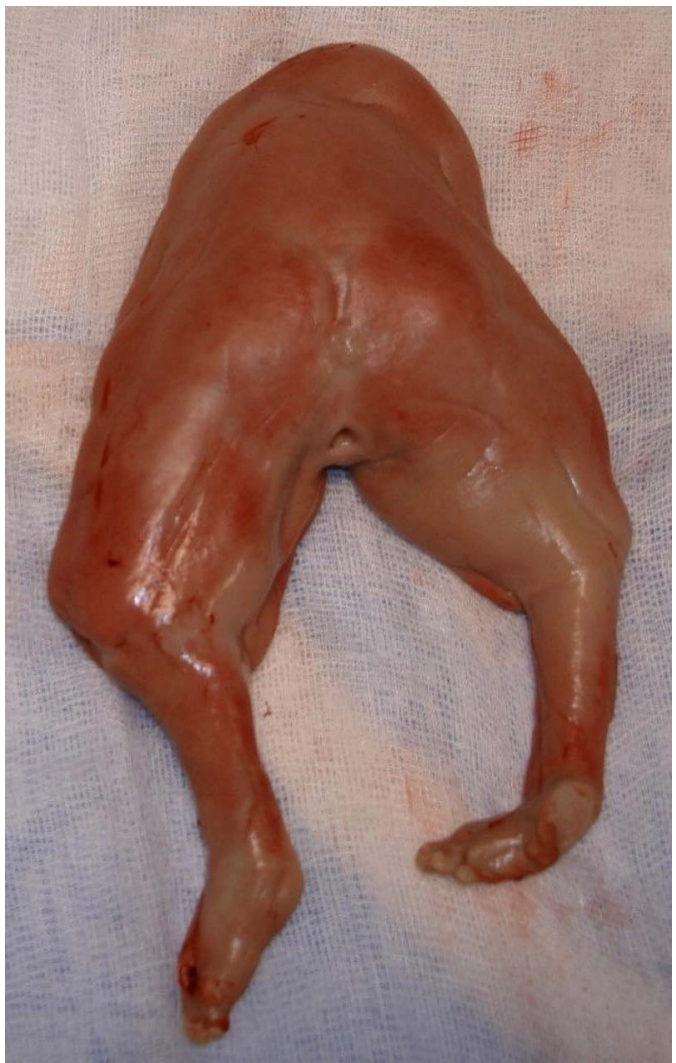

Figure 3 Abnormal fetus—delivered acardiac mass. 


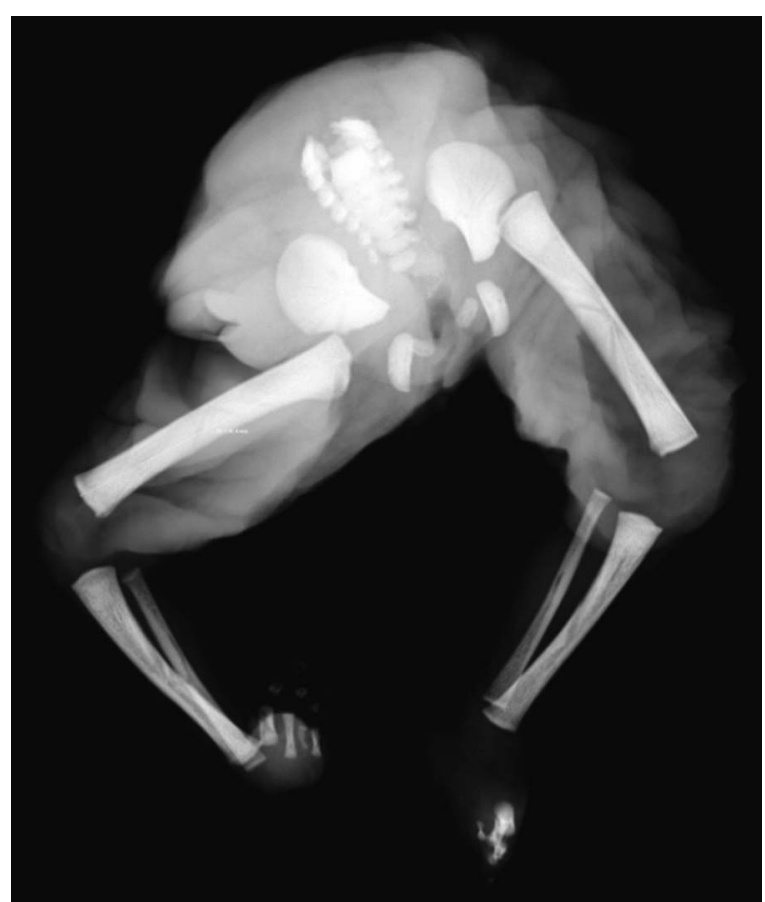

Figure 4 X-ray of acardiac mass.

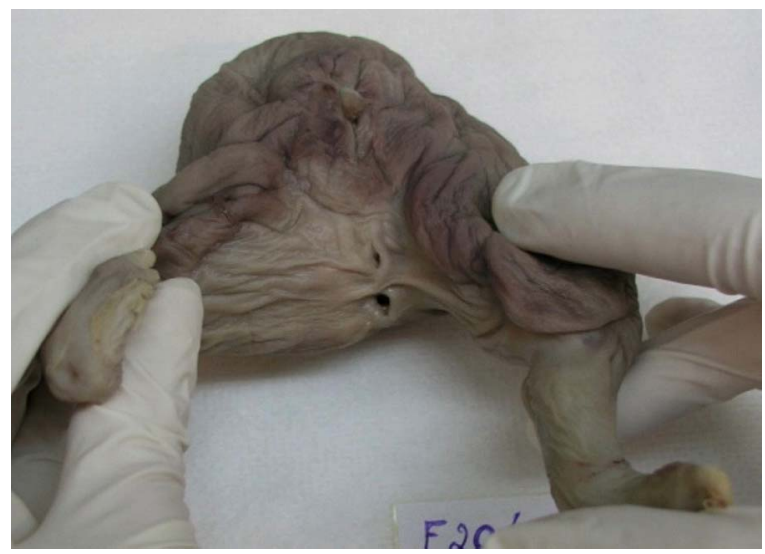

Figure 5 Anatomopathological examination of the acardiac fetus.
Prenatal diagnosis is suspected on first trimester ultrasound, when one fetus appears anatomically normal and the other lacks apparent cardiac structures. Definitive diagnosis is made when pulsatile flow is seen in the umbilical artery going towards the acardius. ${ }^{2}$ Fetuses with signs of high-output cardiac failure have poor prognosis and are candidates for intervention such as target occlusion of the umbilical cord of the acardiac twin, including laser ablation, bipolar cord coagulation or radiofrequency ablation. $^{3}$

\section{Learning points}

- A twin reversed arterial perfusion (TRAP) sequence is rare and occurs in about $1 \%$ of monochorionic twin pregnancies and 1 in 35000 deliveries.

- TRAP should be suspected in monochorionic twin pregnancies when one fetus appears anatomically normal and the other lacks apparent cardiac structures.

- The pump twin is at risk of heart failure and problems related to preterm birth, with a perinatal mortality rate of about $55 \%$ without treatment.

- Surveillance includes weekly ultrasound surveillance to look for the development of fetal hydrops. Fetuses between 18 and 27 weeks of gestation with signs indicative of a poor prognosis are candidates for intervention.

- Continuing pregnancies should be delivered at 34-36 weeks of gestation.

\section{Competing interests None.}

Patient consent None.

Provenance and peer review Not commissioned; externally peer reviewed.

\section{REFERENCES}

1 Gillim DL, Hendricks $\mathrm{CH}$. Holoacardius; review of the literature and case report. Obstet Gynecol 1953:2:647.

2 Bornstein E, Monteagudo A, Dong R, et al. Detection of twin reversed arterial perfusion sequence at the time of first-trimester screening: the added value of 3-dimensional volume and color Doppler sonography. J Ultrasound Med 2008;27:1105.

3 Ville Y, Hyett JA, Vandenbussche FP, et al. Endoscopic laser coagulation of umbilical cord vessels in twin reversed arterial perfusion sequence. Ultrasound Obstet Gynecol 1994;4:396.

Copyright 2014 BMJ Publishing Group. All rights reserved. For permission to reuse any of this content visit http://group.bmj.com/group/rights-licensing/permissions.

BMJ Case Report Fellows may re-use this article for personal use and teaching without any further permission.

Become a Fellow of BMJ Case Reports today and you can:

- Submit as many cases as you like

- Enjoy fast sympathetic peer review and rapid publication of accepted articles

- Access all the published articles

- Re-use any of the published material for personal use and teaching without further permission

For information on Institutional Fellowships contact consortiasales@bmjgroup.com

Visit casereports.bmj.com for more articles like this and to become a Fellow 